\title{
AGAR FILMS: EFFECT OF ADDITIVES ON MECHANICAL PROPERTIES
}

\author{
(C) Demchenko D. V., Pozharitskaya O. N., Shikov A. N.
}

St-Petersburg Institute of Pharmacy, St-Petersburg, Russia

Agar is a gelatinous substance from the red seaweeds (Rhodophycae) and represented by a mixture of agarose and agaropectin. It may be used in tropical countries and by vegetarians and consumers with specific cultural needs (kosher or halal) as a substitute for gelatin. Previously the concentration of agar gel $5 \%$ to form a tensile film suitable for capsulation was selected (1). Agar films without additives had the lowest breaking strength and highest fluidity as compared with gelatin formulation for soft capsules. The purpose of this study was to investigate effect of additives on gelation. Agar films were prepared in different compositions and were contained glycerin, sorbitol, citric acid, sodium citrate, and sodium chloride in different ratios. Experiment was planned by Greco-Latin square design. Optimal compositions were found using programs Statgraphics V. 5.0. and MS Excel. Strength was chosen in the range $0.10-0.13 \mathrm{~kg} / \mathrm{mm}^{2}$ and fluidity was in range $85-95 \mathrm{~mm}$ as optimal parameters of film for capsulation. The regression equation for strength was $Y=0.0748 x_{1}-0.0373 x_{2}+0.3700 x_{3}-0.0872 x_{4}-$
$0.0173 \mathrm{x}_{1} \mathrm{x}_{2}-0.0472 \mathrm{x}_{1} \mathrm{x}_{3}+0.0840 \mathrm{x}_{2} \mathrm{x}_{4}-0.1158 \mathrm{x}_{3} \mathrm{x}_{4}$ $\left(r^{2}=0.94 ; F=14.12\right)$ where $y$ is the strength in $\mathrm{kg} / \mathrm{mm}^{2}$ and $x$ is the amount of additives in $\%\left(x_{1}-\right.$ glycerin, $x_{2}-$ sodium citrate, $x_{3}-$ sodium chloride, $x_{4}-$ citric acid). Citric acid decreased the strength of films, while glycerin, sodium citrate and sodium chloride increased the strength of films. Sorbitol didn't influence on the strength. The regression equation for fluidity was $Y=89.5869+5.4321 x_{1}-3.8437 x_{3}-0.6811 x_{1} x_{2}-$ $1.8460 x_{1} x_{4}-0.6794 x_{2} x_{3}+3.5391 x_{2} x_{4}+1.6022 x_{2} x_{5}$ $\left(r^{2}=0.94 ; F=17.79\right)$ where $y$ is the fluidity in $\mathrm{mm}$ and $x$ is the amount of additives in $\%\left(x_{1}-\right.$ glycerin, $x_{2}-$ sorbitol, $x_{3}$ - sodium citrate, $x_{4}$ - sodium chloride, $x_{5}$ - citric acid). Glycerin increased the fluidity, while sodium citrate decreased the fluidity. Sorbitol, sodium chloride and citric acid didn't influence on the fluidity. The optimal content of additives in agar film was chosen and will be used to produce soft capsules for encasing drugs in the pharmaceutical industry.

Reference: (1) Shikov A. N. Am.-Eurasian J. Sustain. Agric., 2009, 3 (2): 130-134.

\section{DIFFERENTIAL ESTROGENIC ACTIVITY OF PUERARIA MIRIFICA LEAVES DETERMINED BY YEAST ESTROGEN SCREEN HARBORED HUMAN ESTROGEN RECEPTOR-A AND-B}

\section{(c) Dhiani Binar Asrining ${ }^{1,3}$, Jungsukcharoen Jutarmas ${ }^{2}$, Boonchird Chuenchit ${ }^{3}$, Cherdshewasart Wichai ${ }^{2}$}

\begin{abstract}
${ }^{1}$ Fac. of Pharmacy, Muhammadiyah University of Purwokerto, Jalan Raya Dukuhwaluh, Purwokerto Indonesia ${ }^{2}$ Dept.of Biology, Fac.of Science, Chulalongkorn University, Pathumwan Road, Bangkok, Thailand ${ }^{3}$ Dept.of Biotechnology, Fac.of Science, Mahidol University,272 Rama 6 Road, Bangkok, Thailand
\end{abstract}

Leaves of $P$. mirifica, which are available abundant throughout year, were determined its estrogenic activity following the extensive studies of its tuberous part (1-6). Crude extracts of monthly harvested $P$. mirifica leaves from cultivar PM III, PM IV and PM V were subjected to estrogenic activity determination using Yeast Estrogen Screen (YES) method involving human estrogen receptor- (hER-) $\alpha$ and hER- $\beta$. Tuberous extracts were also evaluated as comparison. The yeast strains used in this study were wild type (7) and SNQ2 deletion (snq2 $\Delta$ ) strain. The YES systems were confirmed its sensitivity using pure phytoestrogen compounds prior to determination of the leaves extracts. The results $\left(\mathrm{IC}_{50}\right.$ as parameter) exhibited that $P$. mirifica leaves extracts of all cultivars in all harvested months had higher estrogenic activity determined by YES system harbored hER than $h E R \alpha$. Estrogenic activity was significantly higher $(\mathrm{p} \leq 0.05)$ when $S N Q 2$ deletion was employed. Furthermore, estrogenic activity of $P$. mirifica leaves extracts was slightly lower than its tuberous extracts.

References: (1) Cherdshewasart W, Cheewasopit W, Picha P. J Ethnopharmacol. 2004;93 (2-3):25560. (2) Ito F, Iwasaki M, Watanabe T, Ishikawa T, Higuchi Y. Org Biomol Chem. 2005; (3):674-81. (3) Al-Maharik N, Botting NP. Tetrahedron. 2004;60 (7):1637-42. (4) Chansakaow S, Ishikawa T, Sekine K, Okada M, Higuchi Y, Kudo M, et al. Planta Med. 2000;66 (06):572-75. (5) Malaivijitnond S, Kiatthaipipat P, Cherdshewasart W, Watanabe G, Taya K. J Pharmacol Sci. 2004;96 (4):428-35. (6) Cherdshewasart W, Subtang S, Dahlan W. J Pharmaceut Biomed. 2007;43 (2):428-34. (7) Boonchird C, Mahapanichkul T, Cherdshewasart W. Braz J Med Biol Res. 2010;43:195-200. 